\title{
PENGARUH KONFLIK PERAN, STRES KERJA, LOCUS OF CONTROL, DAN KOMITMEN ORGANISASIONAL TERHADAP TURNOVER INTENTION Studi Kasus pada Kantor Akuntan Publik di Jawa Tengah dan DIY Dyan Kurniawati
Nugraheni Rintasari
}

\begin{abstract}
Public accountant offices have been known of the high level of staff turnover, generally to the new staffs. The turnover level should be decreased work in order to the company has had a change to get the benefit of the work improvement of the staffs. The research aims to test the influence of role conflict, work stress, locus of control, organizational commitment toward the turnover intention on public accountant staffs. The population of the research was public accountants who are working at public accountant offices in Central Java and DIY. The research took the sample using questionnaires. The sampling technique is purposive sampling to the population that was taken by respondent criteria. Based on the criteria, it was obtained that the number of sample was 55 respondents from 13 public accountant offices in Central Java and DIY. The data analysis method is using multiple regression test. The result of analysis showed that the role conflict and the work stress do not give influence toward the turnover intention. However, the locus of control and the organizational commitment give influence toward the turnover intention.
\end{abstract}

Keywords: Role conflict, work stress, locus of control, organizational commitment, turnover intention

\section{PENDAHULUAN}

Saat ini tingginya tingkat keinginan berpindah telah menjadi masalah serius bagi banyak perusahaan. Beberapa kasus tertentu, turnover memang diperlukan oleh perusahaan terutama terhadap karyawan dengan kinerja rendah (Hollenbeck dan Williams, 1986 dalam Toly, 2001). Walaupun begitu, tingkat turnover tersebut harus diupayakan agar tidak terlalu tinggi sehingga perusahaan masih memiliki kesempatan untuk memperoleh manfaat atau keuntungan yang lebih besar atas peningkatan kinerja dari karyawan yang baru dibandingkan biaya rekrutmen yang ditanggung organisasi.

Kantor akuntan publik telah lama dikenal dengan tingginya tingkat turnover staf, umumnya terjadi pada staf yang baru masuk. Sangatlah tidak umum bagi suatu perusahaan kehilangan $20 \%$ sampai $30 \%$ pegawai barunya pada akhir tahun kedua 
pegawai tersebut berkerja (Dwi dan Arif, 2012). Snead dan Harrell (1991) dalam Sijabat (2011) menyatakan tingkat perilaku berpindah kerja (turnover) para profesional di lingkungan Kantor Akuntan Publik (KAP) cukup tinggi. Penelitian Kollaritsh (n.d) dalam Ratnawati (2001) melaporkan tingkat turnover auditor yang bekerja di KAP besar mencapai 85 persen.

Profesi akuntan publik telah dikarakteristikkan sebagai profesi yang memiliki potensi terjadinya konflik dan ketidakjelasan peran (Senatra, 1980 dalam Febrianty, 2012). Konflik peran atau role conflict adalah suatu konflik yang timbul dari mekanisme pengendalian internal birokrasi organisasi yang tidak sesuai dengan norma, aturan, etika, dan kemandirian profesional.

Terlepas dari munculnya konflik peran, stres yang dialami anggota organisasi juga harus diperhatikan. Stres kerja muncul sebagai ketidaksesuaian antara individu dengan lingkungan kerjanya. Stres kerja merupakan stres yang timbul dari beban kerja yang berlebihan dan berbagai tekanan waktu dari tempat kerja seperti pekerjaan-pekerjaan yang dikejar (deadline).

Selain variabel konflik peran dan stres kerja, locus of control juga mempengaruhi tingkat keinginan berpindah karyawan. Menurut (Rotter, 1960) dalam Ardiansah (2003) locus of control merupakan salah satu variabel kepribadian yang didefinisikan sebagai keyakinan individu terhadap mampu tidaknya mengontrol nasib (destiny) sendiri. Bila seseorang mempunyai locus of control eksternal, itu berarti bahwa ia percaya akan kekuatan lingkungan sekitarnya dalam mengendalikan nasibnya. Sebaliknya, locus of control internal menggambarkan kemampuan seseorang dalam menghadapi ancaman apapun yang mungkin timbul dari lingkungannya.

Komitmen organisasional menurut Williams dan Hazer (1986) dalam Toly (2001) merupakan tingkat kekerapan identifikasi dan keterikatan individu terhadap organisasi yang dimasukinya. Karakteristik komitmen organisasional antara lain yaitu loyalitas seseorang terhadap organisasi, kemauan untuk mempergunakan usaha atas nama organisasi, kesesuaian antara tujuan seseorang dengan tujuan organisasi (goal congruence), dan keinginan untuk menjadi anggota organisasi (Porter et al., 1974 dalam Toly, 2001).

Berdasarkan latar belakang maka peneliti tertarik untuk meneliti mengenai 
pengaruh konflik peran, stres kerja, locus of control, dan komitmen organisasional terhadap turnover intention (Studi Kasus pada Kantor Akuntan Publik di Jawa Tengah dan DIY).

\section{TINJAUAN PUSTAKA}

\section{Konflik Peran}

Konflik peran atau role conflict adalah suatu konflik yang timbul dari mekanisme pengendalian internal birokrasi organisasi yang tidak sesuai dengan norma, aturan, etika, dan kemandirian profesional. Kondisi tersebut biasanya terjadi karena adanya dua perintah yang berbeda yang diterima secara bersamaan dan pelaksanaan salah satu perintah saja akan mengakibatkan terabainya perintah yang lain.

Konflik peran (role conflict) diartikan sebagai ketidakcocokan antara harapan seseorang terhadap pekerjaannya dengan tuntutan pekerjaan (Babin dan Boles, 1998) dalam Bhakti (2005). Banyak kondisi yang mendorong terjadinya konflik peran. Konflik peran bisa terjadi ketika karyawan menerima harapan atau tuntutan yang tidak cocok atau saling bertentangan dari dua orang atau pihak atau lebih (misalnya, tuntutan dari rekan kerja versus tuntutan dari atasan, atau tuntutan pelanggan versus atasan) yang tidak mampu dipenuhi atau dipuaskan.

\section{Stres Kerja}

Stres dapat didefinisikan sebagai suatu respon yang dibawa oleh berbagai peristiwa eksternal dan dapat berbentuk pengalaman positif atau pengalaman negatif (Selye, 1976 dalam Suhanto, 2009). Selain itu, Fontana (1989) dalam Suhanto (2009) mendefinisikan stres sebagai suatu tuntutan yang muncul karena adanya kapasitas adaptif antara pikiran dan tubuh atau fisik manusia. Definisi lain tentang stres kerja sebagai tanggapan atau respon yang tidak spesifik dari fisik manusia terhadap tuntutan (demand) yang timbul. Siagian (2007: 305) menyatakan bahwa stres merupakan kondisi ketegangan yang berpengaruh terhadap emosi, jalan pikiran, dan kondisi fisik seseorang. Stres yang tidak diatasi dengan baik biasanya berakibat pada ketidakmampuan seseorang untuk berinteraksi secara positif dengan lingkungannya, baik dalam arti lingkungan pekerjaan maupun lingkungan luar lainnya. 


\section{Locus of Control}

Locus of control adalah persepsi tentang kendali mereka atas nasib, kepercayaan diri dan kepercayaan mereka atas keberhasilan diri. Teori locus of control menggolongkan individu apakah termasuk dalam locus of control internal atau eksternal. Rotter et al. (1990) dalam Pujaningrum (2013) mendefinisikan locus of control sebagai berikut: "Internal control maupun external control adalah tingkatan dimana seorang individu berharap bahwa reinforcement atau hasil dari perilaku mereka bergantung pada perilaku mereka sendiri atau karakteristik personal mereka atau tingkatan dimana seseorang berharap bahwa reinforcement atau hasil adalah fungsi dari kesempatan, keberuntungan atau takdir dibawah kendali yang lain atau tidak bisa diprediksi”.

\section{Komitmen Organisasional}

Komitmen organisasional merupakan rasa identifikasi (ketertarikan dan kepercayaan terhadap tujuan dan nilai organisasi), keterlibatan (kesediaan untuk berusaha sebaik mungkin demi kepentingan organisasi) dan loyalitas (keinginan untuk tetap menjadi anggota organisasi yang bersangkutan) yang dinyatakan oleh seorang pegawai terhadap organisasinya. Komitmen terhadap organisasi artinya lebih dari sekedar keanggotaan formal, karena meliputi sikap menyukai organisasi dan kesediaan untuk mengusahakan tingkat upaya yang tinggi bagi kepentingan organisasi demi pencapaian tujuan. Komitmen terhadap organisasi melibatkan tiga sikap yaitu identifikasi dengan tujuan organisasi, perasaan keterlibatan dalam tugas organisasi, dan perasaan setia terhadap organisasi (Sopiah, 2008: 156).

\section{Turnover Intention}

Turnover intention adalah sikap yang dimiliki oleh anggota organisasi untuk mengundurkan diri dari organisasi. Sebelum turnover terjadi, selalu ada perilaku yang mendahuluinya, yaitu adanya niat atau intensitas turnover. Ada dua pendorong intensitas, yaitu intensitas untuk mencari dan intensitas untuk keluar. Prediktor utama dan terbaik dari turnover adalah intensitas untuk keluar. Intensitas dan perilaku untuk mencari secara umum didahului dengan intensitas untuk keluar (turnover). 


\section{Model Penelitian}

Variabel Independen

Variabel Dependen

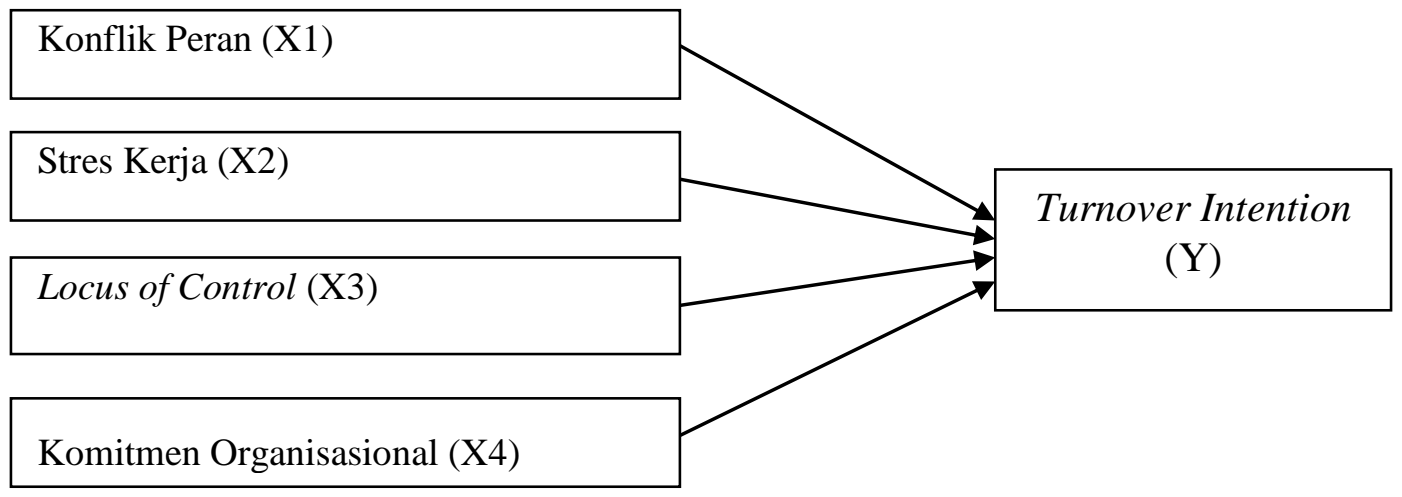

\section{Gambar 1 \\ Model Penelitian}

Rizzo et al. (1970) dalam Bhakti (2005) menggunakan konflik dan ambiguitas peran untuk memprediksi intensi keluar dan turnover, yang menyimpulkan bahwa konflik peran dan ambiguitas peran memiliki dampak pada turnover. Penelitian yang dilakukan Bhakti (2005) menunjukkan bahwa konflik peran berpengaruh negatif dan signifikan terhadap turnover intention. Penelitian ini tidak sejalan dengan penelitian Herdhani (2009) menyatakan ambiguitas peran dan konflik peran berpengaruh positif terhadap keinginan karyawan untuk berpindah pekerjaan. Oleh karena itu, hipotesis pertama penelitian ini yaitu sebagai berikut:

$\mathrm{H} 1=$ Konflik peran berpengaruh terhadap turnover intention .

Toly (2001) menyatakan bahwa stres kerja adalah antaseden utama dari keinginan akuntan untuk berpindah pekerjaan. Didukung penelitian Suhanto (2009) menemukan bahwa terdapat pengaruh positif dan tidak langsung antara stres kerja dengan niat untuk pindah. Penelitian yang dilakukan Waspodo dkk (2013) pada karyawan PT Unitex di Bogor menyatakan stres kerja berpengaruh positif dan signifikan terhadap turnover intention. Oleh karena itu, hipotesis kedua penelitian ini yaitu sebagai berikut:

$\mathrm{H} 2=$ Stres kerja berpengaruh terhadap turnover intention.

Individu dengan locus of control internal memiliki keyakinan tinggi terhadap 
kemampuannya untuk bertahan dalam organisasi karena individu tersebut dapat menyelesaikan semua pekerjaannya dengan baik sehingga kecil kemungkinan untuk mendapat sanksi. Individu dengan locus of control eksternal cenderung selalu ingin berpindah karena takut terhadap kemungkinan diberhentikan bila pekerjaannya terdeteksi tidak sesuai dengan target dan standar yang telah ditentukan. Bila seseorang memiliki locus of control eksternal maka turnover intention semakin tinggi.

Beberapa penelitian telah menemukan hubungan yang signifikan antara locus of control internal dan masa jabatan (job tenure), menunjukan tingkat turnover internal lebih kecil daripada eksternal (Andrisani dan Nestle, 1976; Organ dan Greene, 1974; Harvey, 1971; Donnelly et al., 2003) dalam Rachmawati dkk (2010). Dihipotesiskan bahwa perbedaan yang melekat antara internal dan eksternal akan tampak dalam profesi audit melalui keinginan berpindah kerja. Secara spesifik, eksternal diperkirakan menunjukan tingkat keinginan mengundurkan diri (berpindah kerja) yang lebih tinggi dari pada internal. Donnelly et al. (2003) dan Maryanti (2005) dalam Rachmawati dkk (2010) yang mendukung bahwa eksternal locus of control mempunyai pengaruh yang signifikan dengan turnover intention. Oleh karena itu, hipotesis ketiga penelitian ini yaitu sebagai berikut:

$\mathrm{H} 3$ = Locus of control berpengaruh terhadap turnover intention.

Penelitian yang dilakukan Hom, Katerberg, dan Hulin (1979; 1982); Angle dan Perry (1983) dan Pierce dan Dunham (1987) dalam Ardiansah (2005) menunjukkan hubungan negatif antara komitmen organisasional kemangkiran maupun tingkat perpindahannya karyawan. Penelitian Bhakti (2005) menunjukkan bahwa komitmen organisasional berpengaruh negatif dan signifikan terhadap turnover intention. Berbeda dengan penelitian yang dilakukan Istiqomah (2005) bahwa terdapat pengaruh positif dan signifikan antara komitmen organisasional terhadap keinginan berpindah kerja. Oleh karena itu, hipotesis keempat penelitian ini yaitu sebagai berikut:

$\mathrm{H} 4=$ Komitmen organisasional berpengaruh terhadap turnover intention 


\section{METODA PENELITIAN}

\section{Populasi dan Sampel}

Populasi dalam penelitian ini adalah akuntan publik di Indonesia. Sampel dalam penelitian ini adalah akuntan publik di Jawa Tengah dan DIY. Pengambilan sampel dilakukan secara purposive sampling dengan kriteria staf akuntan publik yang bekerja pada kantor akuntan publik di Jawa Tengah dan DIY. Peneliti membagikan maksimal 5 kuesioner untuk setiap KAP yang diteliti.

\section{Definisi Operasional}

\section{Konflik Peran}

Konflik peran adalah kondisi konflik yang muncul ketika karyawan merasa kesulitan dalam hal menyesuaikan peran yang dimiliki dalam waktu yang bersamaan. Variabel konflik peran diukur dengan instrumen dari Rizzo et al. (1970) dalam Bhakti (2005) instrumen ini terdiri atas 8 item dengan skala 5 poin.

\section{Stres Kerja}

Stres Kerja adalah sebagai kondisi dinamik di mana individu dihadapkan pada suatu peluang, tuntutan, atau sumber daya yang terkait dengan apa yang dihasratkan individu tersebut dan yang hasilnya dipandang tidak pasti dan penting (Robbins, 2008: 368).

\section{Locus of Control}

Locus of Control adalah salah satu variabel kepribadian yang didefinisikan sebagai keyakinan individu terhadap mampu tidaknya mengontrol nasib sendiri. Locus of control diukur menggunakan 16 item pertanyaan Spector (1988) dalam Febrina (2012).

\section{Komitmen Organisasional}

Komitmen organisasional adalah suatu keadaan dimana seseorang karyawan memihak organisasi tertentu serta tujuan-tujuan dan keinginannya untuk mempertahankan keanggotaan dalam organisasi tersebut. Komitmen organisasional diukur dengan mengadaptasi Organizational Commitment Quistionnaire (OCQ) yang dikembangkan oleh Allen Meyer (2003). 


\section{ALAT ANALISIS DATA}

\section{Statistik Deskriptif}

Statistik deskriptif memberikan gambaran atau diskriptif suatu data yang dilihat dari nilai rata-rata, deviasi standar, nilai minimum dan maksimum, range, kurtosis dan skewness (kemencengan distribusi) (Ghozali, 2011: 19).

\section{Uji Kualitas Data}

Uji validitas digunakan untuk mengukur sah atau tidaknya suatu instrumen penelitian, dalam hal ini kuesioner. Suatu kuesiner dinyatakan valid jika pertanyaan pada kuesioner mampu mengungkapkan sesuatu yang diukur oleh kuesioner tersebut (Ghozali, 2006: 45).

Reliabilitas adalah alat untuk mengukur suatu kuesioner yang merupakan indikator dari variabel atau konstruk. Suatu konstruk atau variabel dikatakan reliabel jika memberikan nilai cronbach alpha > 0,60 (Ghozali, 2006: 41).

\section{Analisis Regresi Berganda}

\section{Uji Asumsi Klasik}

\section{1) Uji Normalitas}

Dasar pengambilan keputusan dari uji normalitas adalah dengan melihat probabilitas asymp.sig (2-tailed) > 0,05 maka data mempunyai distribusi normal dan sebaliknya jika probabilitas asymp.sig (2-tailed) $<0,05$ maka data mempunyai distribusi yang tidak normal (Ghozali, 2006: 147).

2) Uji Heteroskedastisitas

Uji statistik yang digunakan dalam penelitian untuk mengetahui ada tidaknya heteroskedatisitas yaitu uji Glejser. Jika nilai signifikansi diatas nilai alpha $(0,05)$ maka model regresi tidak mengandung adanya heteroskedasitas (Ghozali, 2006: 125).

3) Uji Multikolinearitas

Uji multikolinieritas dilakukan untuk menguji apakah pada model regresi ditemukan adanya variabel yang saling berkorelasi antar variabel bebas. Dasar pengambilan keputusan adalah apabila nilai tolerance $<0,1$ atau sama dengan nilai VIF > 10 berarti terjadi multikolinearitas antar variabel dalam regresi (Ghozali, 2006: 91). 


\section{Pengujian Hipotesis}

1) Koefisien Determinasi

Koefisien determinasi $\left(\mathrm{R}^{2}\right)$ digunakan untuk mengukur seberapa jauh kemampuan model dalam menjelaskan variasi variabel dependen. Nilai koefisien determinasi adalah antara nol sampai dengan satu (Ghozali, 2011: 97).

2) Uji F

Uji F digunakan untuk membuktikan secara statistik koefisien regresi juga signifikan. Jika signifikansi $\mathrm{F}<0,05$ maka semua variabel independen secara simultan merupakan penjelas variabel dependen (Ghozali, 2011: 98).

3) Uji t

Uji $\mathrm{t}$ digunakan untuk mengetahui pengaruh masing-masing variabel independen terhadap variabel dependen. Uji t statistik dilakukan dengan cara membandingkan antara nilai signifikansi dari uji t tersebut dengan tingkat kesalahan (a) 5\% (Ghozali, 2011: 99).

\section{HASIL DAN PEMBAHASAN}

\section{Gambaran Umum Responden}

Penelitian ini menggunakan data primer dengan menyebarkan kuesioner pada kantor akutan publik di Jawa Tengah dan DIY. Jumlah kuesioner yang disebarkan 73 buah, yang kembali 60 buah, dan yang dapat diolah dalam penelitian ini sebanyak 55 buah, 5 buah dianggap gugur karena tidak sesuai kriteria.

\section{Statistik Deskriptif}

Tabel 1

Hasil Statistik Deskriptif

\begin{tabular}{|l|c|c|c|c|c|c|c|}
\hline & Range & Min & Max & Sum & Mea & $\begin{array}{c}\text { Std. } \\
\text { Deviasi }\end{array}$ & N \\
\hline Konflik Peran & 16 & 20 & 36 & 1658 & 30,15 & 4,692 & 55 \\
\hline Stres Kerja & 35 & 35 & 70 & 3094 & 56,25 & 8,349 & 55 \\
\hline Locus of & 31 & 36 & 67 & 3067 & 55,76 & 7,19 & 55 \\
\hline $\begin{array}{l}\text { Komitmen } \\
\text { Organisasional }\end{array}$ & 33 & 24 & 57 & 2551 & 46,38 & 6,291 & 55 \\
\hline $\begin{array}{l}\text { Turnover } \\
\text { Intention }\end{array}$ & 10 & 18 & 28 & 1278 & 23,24 & 2,252 & 55 \\
\hline
\end{tabular}


Sumber: Data primer, diolah (2015)

Tabel 1 menjelaskan bahwa pada variabel konflik peran jumlah responden $(\mathrm{N})$ ada 55, dari 55 responden ini jawaban terkecil (Minimum) adalah 20 dan terbesar Maximum) adalah 36. Rata-rata total jawaban konflik peran adalah 30,15 dengan standar deviasi 4,692. Nilai range merupakan selisih nilai maksimum dan minimum sebesar 16 dan nilai sum merupakan penjumlahan dari 55 responden yaitu sebesar 1658. Selanjutnya pada variabel stres kerja menunjukkan jumlah responden 55, dari 55 responden ini jawaban terkecil (minimum) adalah 35 dan terbesar (maximum) adalah 70. Rata-rata total jawaban stres kerja 56,25 dengan deviasi standar 8,349. Nilai range merupakan selisih nilai maksimum dan minimum sebesar 35 dan nilai total penjumlahan sebesar 3094.

Variabel locus of control menunjukkan jumlah responden 55, dari 55 responden ini jawaban terkecil (minimum) adalah 36 dan terbesar (maximum) adalah 67. Ratarata total jawaban locus of control 55,76 dengan deviasi standar 7,190. Nilai range sebesar 31 dan nilai sum sebesar 3067. Selanjutnya, variabel turnover intention menunjukkan jumlah responden 55, dari 55 responden ini jawaban terkecil (minimum) adalah 18 dan terbesar (maximum) adalah 28. Rata-rata total jawaban turnover intention 23,24 dengan deviasi standar 2,252. Nilai range sebesar 10 dan nilai sum sebesar 1278.

\section{Uji Kualitas Data}

Hasil uji validitas menunjukkan bahwa ada satu item pertanyaan pada variabel locus of control tidak valid. Sementara itu, hasil uji reliabilitas terhadap masingmasing kuesioner pengukuran variabel menunjukkan bahwa kuesioner yang digunakan dalam penelitian ini secara statistik layak digunakan sebagai alat pengumpul data, karena syarat validitas dan reliabilitasnya telah terpenuhi.

\section{Analisi Regresi Berganda}

\section{Uji Asumsi Klasik}

1) Uji Normalitas

Hasil uji normalitas pada tabel 2 menunjukkan bahwa besarnya nilai asymp. sig. (2-tailed) adalah 0,860 lebih besar dari nilai alpha $(0,05)$ maka dapat diketahui bahwa data residual terdistribusi secara normal. 
Tabel 2

Hasil Uji Normalitas

\begin{tabular}{|c|c|c|}
\hline Keterangan & Unstandardized Residual & Alpha \\
\hline N & 55 & \multirow{2}{*}{0,05} \\
\hline Asymp. Signifikansi (2-tailed) & 0,860 & \\
\hline
\end{tabular}

Sumber: Data primer, diolah (2015)

2) Uji Heteroskedastisitas

Berdasarkan hasil yang ditunjukkan oleh tabel 3 nilai signifikansi untuk variabel independen lebih besar dari nilai alpha $(0,05)$ maka dapat diketahui model regresi tidak terdapat gejala heterokedastisitas yaitu ketidaksamaan variance dari residual satu pengamatan ke pengamatan lain.

Tabel 3

Hasil Uji Heteroskedastisitas

\begin{tabular}{|l|c|c|c|}
\hline \multicolumn{1}{|c|}{ Variabel } & Signifikansi & Alpha & Keterangan \\
\hline Konflik Peran & 0,202 & 0,05 & Tidak ada heteroskedastisitas \\
\hline Stres Kerja & 0,185 & 0,05 & Tidak ada heteroskedastisitas \\
\hline Locus of Control & 0,910 & 0,05 & Tidak ada heteroskedastisitas \\
\hline Komitmen Organisasional & 0,595 & 0,05 & Tidak ada heteroskedastisitas \\
\hline
\end{tabular}

Sumber: Data primer, diolah (2015)

3) Uji Multikolinieritas

Berdasarkan hasil yang ditunjukkan oleh tabel 4.13, nilai tolerance pada masing-masing variabel independen $>0,1$ dan nilai variance inflation factor (VIF) $<$ 10 maka dapat diketahui model regresi tidak terdapat multikolinearitas.

Tabel 4

Hasil Uji Multikolinearitas

\begin{tabular}{|l|c|c|l|}
\hline \multicolumn{1}{|c|}{ Variabel Independen } & Tolerance & VIF & \multicolumn{1}{c|}{ Keterangan } \\
\hline Konflik Peran & 0,306 & 3,269 & Tidak ada multikolinieritas \\
\hline Stres Kerja & 0,208 & 4,799 & Tidak ada multikolinieritas \\
\hline Locus of Control & 0,619 & 1,616 & Tidak ada multikolinieritas \\
\hline Komitmen Organisasional & 0,407 & 2,458 & Tidak ada multikolinieritas \\
\hline
\end{tabular}

Sumber: Data primer, diolah (2015) 


\section{Uji Hipotesis}

Tabel 5

Hasil Uji Regresi Linear Berganda

\begin{tabular}{|c|l|c|c|}
\hline No & \multicolumn{1}{|c|}{ Variabel } & Signifikansi & Alpha \\
\hline 1 & Konflik Peran & 0,755 & 0,05 \\
\hline 2 & Stres Kerja & 0,980 & 0,05 \\
\hline 3 & Locus of Control & 0,011 & 0,05 \\
\hline $4 \quad$ & Komitmen Kerja & 0,035 & 0,05 \\
\hline Variabel Dependen $=$ Turnover Intention & \\
F Statistik $=8,077$ & \\
Signifikansi $\quad=0,000^{\mathrm{b}}$ & & \\
Adjusted $R^{2} \quad=0,344$ & & \\
\hline
\end{tabular}

Sumber: Data primer, diolah (2015)

Berdasarkan tabel 5 nilai adjusted $R$-square sebesar 0,344. Hal ini berarti 34,4\% variabel dependen (turnover intention) dapat dijelaskan oleh keempat variabel independen yaitu konflik peran, stres kerja, locus of control, dan komitmen organisasional. Sedangkan sisanya $(100 \%-34,4 \%=65,6 \%)$ dijelaskan oleh faktorfaktor lain di luar model yang diteliti dalam penelitian ini.

Berdasarkan tabel hasil perhitungan statistik $\mathrm{F}$ sebesar 8,077 dengan nilai signifikansi 0,000. Signifikansi jauh lebih kecil dari 0,05 yang berarti secara simultan seluruh variabel independen berpengaruh secara signifikansi terhadap variabel dependen. Model regresi ini dapat menjelaskan bahwa konflik peran, stres kerja, locus of control, dan komitmen organisasional secara bersama-sama berpengaruh terhadap turnover intention akuntan publik.

\section{Konflik peran terhadap turnover intention akuntan publik}

Hasil dari analisis regresi menunjukkan nilai koefisien regresi -0,030 dengan nilai signifikansi 0,755 . Karena nilai signifikansi lebih besar dari nilai alpha $(0,05)$ maka $\mathrm{H}_{1}$ ditolak. Jadi konflik peran tidak berpengaruh terhadap turnover intention akuntan publik. Hasil penelitian ini berbeda dengan hasil yang dilakukan oleh Herdhani (2009) yang menyatakan bahwa konflik peran berpengaruh positif terhadap keinginan auditor untuk berpindah pekerjaan.

\section{Stres Kerja terhadap turnover intention akuntan publik}

Hasil dari analisis regresi menunjukkan nilai koefisien regresi 0,002 dengan 
nilai signifikansi 0,980 . Karena nilai signifikansi lebih besar dari nilai alpha $(0,05)$ maka $\mathrm{H}_{2}$ ditolak. Jadi stres kerja tidak berpengaruh terhadap turnover intention akuntan publik. Hasil penelitian ini berbeda dengan hasil yang dilakukan oleh Waspodo, dkk (2013) yang menyatakan bahwa stres kerja berpengaruh terhadap keinginan auditor untuk berpindah pekerjaan.

\section{Locus of control terhadap turnover intention akuntan publik}

Hasil dari analisis regresi menunjukkan nilai koefisien regresi 0,115 dengan nilai signifikansi 0,011. Karena nilai signifikansi lebih kecil dari nilai alpha $(0,05)$ maka $\mathrm{H}_{3}$ diterima. Jadi locus of control berpengaruh terhadap turnover intention akuntan publik. Meningkatnya locus of control akan diikuti dengan menurunnya turnover intention akuntan publik, dan begitu pula sebaliknya.

\section{Komitmen organisasional terhadap turnover intention akuntan publik}

Hasil dari analisis regresi menunjukkan nilai koefisien regresi 0,134 dengan nilai signifikansi 0,035 . Karena nilai signifikansi lebih kecil dari nilai alpha $(0,05)$ maka $\mathrm{H}_{4}$ diterima. Jadi komitmen organisasional berpengaruh terhadap turnover intention akuntan publik. Peningkatan komitmen organisasional akan diikuti dengan menurunnya turnover intention akuntan publik, dan begitu pula sebaliknya. Hasil ini konsisten dengan hasil penelitian yang dilakukan oleh Istiqomah (2005) bahwa terdapat pengaruh positif dan signifikan antara komitmen organisasional terhadap keinginan berpindah kerja auditor.

\section{SIMPULAN, KETERBATASAN, DAN SARAN}

Berdasarkan analisis data yang telah diuraikan maka dapat disimpulkan bahwa konflik peran dan stres kerja tidak berpengaruh terhadap turnover intention akuntan publik. Locus of control dan komitmen organisasi berpengaruh terhadap turnover intention akuntan publik.

Keterbatasan dalam penelitian ini adalah kurangnya responden yang menjadi objek penelitian karena hanya beberapa KAP yang memberikan izin penelitian, hal ini disebabkan karena waktu penyebaran kuesioner pada saat KAP sedang sibuk dan akuntan publik yang menjadi objek penelitian sedang tugas ke luar kota. 
Saran yang diajukan dalam penelitian ini adalah:

1. Teknik pengumpulan data tidak hanya dilakukan dengan penyebaran kuesioner, sebaiknya peneliti selanjutnya mengumpulkan data dengan melakukan teknik wawancara secara langsung sehingga dapat memperoleh informasi yang lebih lengkap.

2. Sebaiknya penyebaran kuesioner dilakukan pada masa-masa saat Kantor Akuntan Publik (KAP) tidak sibuk agar semua KAP bersedia mengisi kuesioner.

3. Penelitian selanjutnya disarankan untuk menambah variabel lain yang lebih berpengaruh terhadap turnover intention akuntan publik, misalnya motivasi.

\section{DAFTAR PUSTAKA}

Adinata, Irwanto. 2013. "Pengaruh Konflik Peran, Stres Kerja, dan Self Efficacy terhadap Komitmen Organisasional (Studi Empiris pada KAP di Semarang)" Tesis Universitas Katolik Soegijapranata, Semarang [Online]. Didapatkan: <http://eprints.unika.ac.id/15571.pdf [17> November 2014].

Ardiansah, Muhammad Noor. 2003. "Pengaruh Gender dan Locus of Control terhadap Kepuasan Kerja, Komitmen Organisasional, dan Keinginan Berpindah Kerja Auditor (Studi pada Auditor KAP di Pulau Jawa)". Tesis Universitas Diponegoro Semarang [Online] Didapatkan: <http://www.academia.edu/3473366/pengaruh_gender_dan_locus_of_cont rol_terhadap_kepuasan_kerja_komitmen_organisasional_dan_keinginan_ber pindah_kerja_.pdf [18> November 2014]

Bhakti, Septa Jangkung Waskita. 2005."Pengaruh Kepuasan Kerja, Komitmen Organisasi, Konflik Peran, dan Ambiguitas Peran terhadap Turnover Intention (Studi Empiris pada KAP di Semarang)". Skripsi Universitas Katolik Soegijapranata Semarang [Online]. Didapatkan: <http://eprints.unika.ac.id/11667.pdf [18> November 2014.

Budyman, Fitra. 2007. "Pengaruh Tekanan Peran (Role Stress) Terhadap Keinginan Untuk Berpindah Pekerjaan (Studi Survey pada KAP di Bandung". Thesis Universitas Kristen Maranatha, Bandung [Online]. Didapatkan: $<$ http://repository.maranatha.edu/view/creators/Budyman=3AFitra_=28_0 $351254 \_=29=3 \mathrm{~A}=3 \mathrm{~A} . \mathrm{html}[18>$ November 2014]

Dwi, Cristine, Dan Arif Setiawan. 2012. Pengaruh Persepsi Mahasiswa Akuntansi 
Mengenai Lingkungan Kerja Auditor terhadap Pilihan Karirnya Sebagai Auditor di KAP (Studi Kasus pada Mahasiswa Akuntansi Universitas Kristen Maranatha dan Universitas Parahyangan). Jurnal Ilmiah Akuntansi, Nomor 08, Mei-Agustus 2012: 1-13.

Febrianty. 2012. Pengaruh Role Conflict, Role Ambiguity, dan Work-Family Conflict terhadap Komitmen Organisasional (Studi Pada KAP di Sumatera Bagian Selatan). Jurnal Ekonomi dan Informasi Akuntansi, Vol.2, September 2012: 315-339.

Febrina, Husna Lina. 2012. "Analisis Pengaruh Karakteristik Personal Auditor terhadap Penerimaan Auditor Atas Dysfunctional Audit Behavior (Studi Empiris pada KAP di Jateng dan DIY)". Skripsi Universitas Diponegoro Semarang [Online]. Didapatkan: <http://eprints.undip.ac.id/35521/1/Skripsi_29.pdf [17> November 2014.

Ghozali, Imam. 2006. Aplikasi Analisis Multivariate dengan Program SPSS, Edisi Ketiga. Semarang : Badan Penerbit Universitas Diponegoro.

Ghozali, Imam. 2011.Aplikasi Analisis Multivariate dengan Program IBM SPSS 19, Edisi Kelima. Semarang : Badan Penerbit Universitas Diponegoro.

Herdhani. 2009. "Pengaruh Ketidakjelasan Peran dan Konflik Peran terhadap Keinginan Berpindah Auditor (studi Empiris KAP di Semarang)". Thesis Universitas Katolik Soegijapranata, Semarang [Online]. Didapatkan: http://eprints.unika.ac.id/view/creators/Herdhani=3A_=3A=3A.html November 2014].

Heriyanti, Dewita. 2007. "Analisis Pengaruh Budaya Organisasi, Kepuasan Kerja,dan Gaya Kepemimpinan terhadap Kinerja Karyawan dengan Komitmen Organisasional sebagai Variabel Intervening”. Tesis Universitas Diponegoro, Semarang [Online]. Didapatkan: <http://eprints.undip.ac.id/16969/1/ Dewita_Heriyanti.pdf [17> November 2014.

Istiqomah, Inuk Wahyuni. 2005. "Pengaruh Kepuasan Kerja, Komitmen Organisasional, dan Komitmen Profesional terhadap Keinginan Berpindah Kerja Pada KAP di Jawa Timur" [Online]. Didapatkan: http://download.portalgaruda.org/article.php?article=9597\&val=621 September 2014].

Karina, Andindya. 2014. "Pengaruh Komunikasi Organisasional Untuk Mengatasi Turnover Intention Melalui Stress Kerja di Akuntan Publik". Thesis Universitas Katolik Soegijapranata, Semarang [Online]. Didapatkan: $<$ http://eprints.unika.ac.id/15669.pdf [03> November 2014].

Pujaningrum, Intan. 2012. "Analisis Faktor-Faktor yang Mempengaruhi Tingkat Penerimaan Auditor Atas Penyimpangan Perilaku dalam Audit (Studi Empiris pada KAP di Semarang)". Skripsi Universitas Diponegoro, Semarang 
[Online] Didapatkan: <http://eprints.undip.ac.id/37197/1 /PUJANINGRUM.pdf [17> November 2014].

Putra, Dipo Binta. 2014. "Pengaruh Stres Kerja dan Perkembangan Karir terhadap Turnover Intention Akuntan Junior melalui Kepuasan Kerja pada Kantor Akuntan Publik di Semarang". Skripsi Universitas Katolik Soegijapranata, Semarang [Online]. Didapatkan: <http://eprints.unika.ac.id/15657.pdf [18>November 2014]

Rachmawati, Novida Dwi dan Ardiani Ika Sulistyawati. 2010. "Pengaruh Locus Of Control, Relativism, Komitmen Organisasi, Kinerja dan Turnover Intention terhadap Dysfunctional Audit Behavior (Studi Empiris pada Kantor Akuntan Publik di Jawa Tengah)". [Online] Didapatkan: <http://digilib.usm.ac.id/gdl.php?mod=browse\&op=read\&id=gdl-usm-novidadwir-188 [18> November 2014].

Ratnawati, V. 2001. "Pengaruh Faktor Anteseden, Job Insecurity, dan Konsekuensinya terhadap Keinginan Berpindah KaryawanStudi Empiris pada Kantor Akuntan Publik Indonesia”. Simposium Nasional Akuntansi IV. Ikatan Akuntan Indonesia. Hal. 411-428.

Robbins, Stephen P., dan Timothy A. Judge. 2008. Perilaku Organisasi, Edisi 12. Jakarta: Salemba Empat.

Siagian, Sondang P. 2007. Manajemen Sumber Daya Manusia. Jakarta: Bumi Aksara.

Sijabat, Jadongan. 2011. Analisis Keinginan Untuk Pindah: Studi Empiris Pada KAP Besar di Jakarta yang Berafiliasi Dengan KAP Asing (The Big Four)" Jurnal Akuntansi Bisnis, Vol. IX, Maret 2011: 95-109.

Sopiah. 2008. Perilaku Organisasional. Yogyakarta: Andi Offset.

Suhanto, Edi. 2009. "Pengaruh Stres Kerja dan Iklim Organisasi Terhadap Turnover Intention Dengan Kepuasan Kerja Sebagai Variabel Intervening (Studi di Bank Internasional Indonesia)". Thesis Universitas Diponegoro, Semarang [Online]. Didapatkan: <http:// eprints.undip.ac.id/17248/1/ EDI_SUHANTO.pdf [23> November 2014].

Suryana, Fajar Hadi. 2013. "Pengaruh Struktur Audit, Komitmen Organisasi, Konflik Peran dan Efektivitas Penggunaan Teknologi Sistem Informasi Akuntansi terhadap Kinerja Auditor". Skripsi Universitas Islam Negeri Syarif Hidayatullah, Jakarta [Online]. Didapatkan: <http://repository.uinjkt.ac.id/ dspace/bitstream/123456789/23982/1/Skripsii\%20Fajar\%20Hadi\%20\%28108 082000109\%29.html [26> November 2014].

Toly, A.A. 2001. "Analisis Faktor-Faktor Yang Mempengaruhi Turnover Intentions Pada Staf Kantor Akuntan Publik", Jurnal Akuntansi \& Keuangan .Vol.3. 
November 2001: 102-125.

Waspodo, Agung AWS, Nurul Chotimah Handayani, dan Widya Paramita. 2013. "Pengaruh Kepuasan Kerja dan Stres Kerja terhadap Turnover Intention pada Karyawan PT. Unitex di Bogor" Jurnal Riset Manajemen Sains(JRMSI). Vol.4. Hal. 97-115. 